\title{
STUDY ON THE TAXATION OF THE INCOME OBTAINED FROM THE CRYPTOCURRENCY TRANSFER
}

\author{
Lucian Cernușca* \\ "Aurel Vlaicu” University of Arad, România, E-mail: luciancernusca@gmail.com
}

Bogdan Cosmin Gomoi

"Aurel Vlaicu” University of Arad, România, E-mail: bogdan_gomoi@yahoo.com

Raluca Simina Bilți

"Aurel Vlaicu” University of Arad, România, E-mail: raluca.bilti@uav.ro

Robert Cristian Almași

"Aurel Vlaicu” University of Arad, România, E-mail: robert.almasi@uav.ro

(Received: September 2020; Accepted: October 2020; Published: November 2020)

\begin{abstract}
This article discusses a number of conceptual and practical issues regarding the taxation of the income coming out from the transfer of virtual currency. The individuals who earn constant money from cryptocurrencies (over 600 lei per year) have the obligation to report their income yearly and to pay the income tax and the health insurance contributions in certain situations. According to the provisions of the Tax Code, the gains from cryptocurrency transfers will fall into the category of the taxable income from other sources. For individuals, this income will be declared through the Single Taxation Statement during the year following the year of its realization. Specifically, the earnings from cryptocurrencies in 2019 will be declared in 2020. As long as an individual keeps his income from cryptocurrencies in the form of cryptocurrencies, without actually using them, he is not obliged to declare them and pay the income tax and the Social health insurance contribution for them.
\end{abstract}

Keywords: cryptocurrencies, Single Taxation Statement, income tax, health contribution, Tax Code.

\section{Introduction}

Revenues obtained from the cryptocurrency transfer have to be declared, for the first time, in 2020, once the Tax Code has undergone several changes in order to

\footnotetext{
${ }^{*}$ Corresponding author: Lucian Cernușca.E-mail: luciancernusca@gmail.com.
}

Copyright (C) 2020 The Author(s). Published by VGWU Press

This is an Open Access article distributed under the terms of the Creative Commons BY 4.0 license (Creative Commons - Attribution 4.0 International - CC BY 4.0) which permits unrestricted use, distribution, and reproduction in any medium, provided the original author and source are credited. 
make their reporting officially mandatory. Thus, for the earnings obtained from the cryptocurrency in 2019, taxpayers have the obligation to submit the single taxation declaration through which they declare their payment obligations to the state budget as an income tax and, in some cases, the social health insurance contribution. The Fifth Money Laundering Directive (Directive 2018/843), adopted in 2018, defines "the cryptocurrencies" as a digital value representation that is not issued or guaranteed by a central bank or public authority, which is not necessarily linked to a legal currency and which does not own the legal status of a currency, but which can be accepted by individuals or legal entities as a mean of exchange and which can be transferred, stored and traded through electronic means; according to the same directive, the functions/uses of cryptocurrencies are payment, exchange, investment means, value storage product or for online casinos use. (Banu \& Clem, 2019).

Raluca Bontaş and Cătălin Barbu, Deloitte Tax specialists, state that "In the context in which cryptocurrencies are not recognized as currencies in the Romanian or European legislation, electronic currencies or real currencies, we believe that the individual acquires a real benefit only at the time of conversion of these cryptocurrency units in currency units of currency, legal tender (for example, income statement in the bank account) or in goods or services that the individual actually benefits from. An opposite interpretation would not be practical, given the volatility of cryptocurrencies and the fact that transactions are usually conducted through trading platforms whose settlement is uncertain (not regulated, supervised or controlled by state institutions) and the individual could end up paying a tax on a hypothetical income (...) "However, the anonymous, encrypted and unregulated nature of cryptocurrency transactions must be taken into account, as it makes it impossible for both the taxpayer and the tax authority to declare and tax those elements of income as long as they do not crystallize and are not distinctly outlined in a regulated financial ecosystem". Therefore, as long as a person keeps his cryptocurrencies income as a cryptocurrency, without actually using them, he does not have to declare them and pay taxes for them.

\section{Statement and payment obligations}

In case the annual net income exceeds the legal ceiling, taxpayers who obtain income from the transfer of cryptocurrency have to pay both the income tax and social contributions.

- Income Tax

Through the Law no. 30/2019 approving the Government Emergency Ordinance no. $25 / 2018$ on amending and supplementing some regulations, as well as for the approval of some fiscal-budget measures, a series of amendments were made to the Tax Code regarding the regulation of the fiscal regime applicable to the revenues 
Cernușca, L., Gomoi, B.C., Bilți, R.S., Almași, R.C., (2020)

Study on the taxation of the income obtained from the cryptocurrency transfer

obtained from the cryptocurrency transfer. As of April 1, 2019, revenues from cryptocurrency transfers fall into the category of revenues from other sources.

Table 1 Taxation of income obtained from cryptocurrency transfer

\begin{tabular}{|l|l|}
\hline \multicolumn{1}{|c|}{ Year 2019 } & \multicolumn{1}{|c|}{ Year 2020 } \\
\hline $\begin{array}{l}\text { Earnings obtained from the transfer of } \\
\text { cryptocurrency exceeding 601 lei }\end{array}$ & $\begin{array}{l}\text { The taxpayer submits the single } \\
\text { taxation statement by the legal } \\
\text { deadline provided in the Tax Code } \\
\text { Income tax }=10 \% \times \text { (revenue } \\
\text { obtained which represents the positive } \\
\text { difference between the sale price and } \\
\text { the purchase price, including direct } \\
\text { transaction costs) }\end{array}$ \\
\hline $\begin{array}{l}\text { Earnings from the transfer of of } \\
\text { cryptocurrency below the level of 200 } \\
\text { lei/transaction }\end{array}$ & $\begin{array}{l}\text { The taxpayer does not submit the } \\
\text { single taxation statement, such } \\
\text { revenue is not taxed provided that the } \\
\text { total earnings in a fiscal year do not } \\
\text { exceed the level of 600 lei. }\end{array}$ \\
\hline
\end{tabular}

- Social contributions

Earnings from cryptocurrency transactions are exempt from the payment of the social insurance contribution (CAS), but not from the social health insurance contribution (CASS). Taxpayers who obtain income from cryptocurrency transfer fall under the obligation to pay the social health insurance contribution in certain cases may. In accordance with the provisions of the Tax Code, they must pay the CASS if they estimate earnings for the current year (either from cryptocurrencies transaction or by cumulating these incomes with other incomes, as provided in art. 155 of the Tax Code) whose cumulated value is at least equal to 12 minimum gross wages per country. For such incomes, CASS is due in the situation when the ceiling of 24,960 lei for 2019 and 26,760 lei for 2020 is exceeded.

If, by summing up these estimated incomes, the ceiling has been exceeded, the taxpayer will owe the contribution to social health insurance contribution in the amount of $10 \%$, at a monthly taxable base located at the level of the minimum gross wage per economy.

\section{Literature review}

The state introduced in 2019, in Romania, a tax, expressly defined, on the sale of virtual currencies, such as Bitcoin and Ethereum, by amending the Tax Code (Zamfir, 2019). We are talking about Law no. 30/2019, which approves and 
Cernușca, L., Gomoi, B.C., Bilți, R.S., Almași, R.C., (2020)

Study on the taxation of the income obtained from the cryptocurrency transfer

amends GEO no. 25/2018, thus making several changes within the Tax Code. This law includes the earnings from bitcoin and other digital currencies within the „revenue from other sources" category. Overall, the legislation also becomes permissive for those who trade cryptocurrencies, so that a much more rigorous regulation is conveyed internationally. Now, the lawmakers offer a number of benefits to those who trade cryptocurrencies (Ciutacu, 2019). Popular cryptocurrencies are Bitcoin (BTC), Ethereum (ETH), Litecoin (LTC), Ripple (XRP) and Monero (XMR). Cryptocurrency's entrance into the market represents the next stage in efficient transacting (Ankier, 2014, p.883). A „cryptocurrency”, generally, is a digital or virtual currency that functions as a medium of exchange by using encryption in lieu of a centralized issuing or regulatory authority to verify transactions and to manage the issuance of new coins (Semanski, 2018,p.8). Cryptocurrency is a digital currency that uses encryption techniques, rather than a central bank, to generate, exchange, and transfer units of currency. Unlike cash transactions, no bank or government authority verifies the transfer of funds. Instead, these virtual transactions are recorded in a digitized public ledger called a "blockchain.” Individual units of the currency are called „coins.”(Lerer, 2020).

Mantu (2019) considers that cryptocurrencies ,arose from the need to use an alternative currency, which does not require the presence of a managing authority, which operates beyond the political climate and which is easy to transfer".

The general characteristics of cryptocurrencies are:

- They are unidirectional - once the network has approved the transaction made by sending to another person, the transmission/payment cannot be canceled anymore, unless the beneficiary wants to send it to you;

- They can be used only through a digital wallet without needing an identity card so that you can practically remain anonymous;

- They are fast and can be obtained by anyone, anywhere in the world;

- The number of cryptocurrencies is limited (Mantu, 2019).

The use of cryptocurrencies and the benefits of the blockchain technology make their presence felt with timid steps in Romania. The entrepreneurial environment is stimulated a little at all, and the process of technological innovation is encouraged below the optimal level. Duiu (2020b) suggests that ,it is important to be constantly informed about the news and the progress made within the digital world, while seeking to take advantage of this fact, adapting to the era in which we live. We need to read, to look for information from several sources, to test, to be curious, but, at the same time, to be cautious, to be grateful that we were born in these times when the technology makes everything much easier. Let's use it in good faith and try not to dehumanize ourselves, at the same time".

Romania is one of the few countries that has adapted its tax system in order to include the cryptocurrency revenues. Nevertheless, it will be very difficult for the 
Romanian authorities to have a clear representation of these gains, because the cryptocurrency transactions are anonymous, and a Romanian citizen can choose an exchange from outside Romania, or even from outside the European Union area, where there are no taxes. In addition, it seems that the state will no longer be able to confiscate the currency found on a citizen at the customs, even if he cannot justify its origin (Tradesilvania, 2020).

According to Duiu (2020a) the cryptocurrencies, as well as the distributed register technology (the TRD that underlies them) have a huge potential to change the financial services by increasing the speed and by reducing the business costs. However, bringing digital currencies to light will require a collaborative effort for the international bodies, the individual governments and the financial services industry in order to implement coherent and consistent verification protocols. Much like blockchain, cryptocurrencies have become a "buzzword" to refer to a wide array of technological developments that utilize a technique better known as cryptography (Houben \& Snyers, 2018, p.20).

When investors buy and sell Bitcoin on the various Bitcoin exchanges, these transactions would continue to be taxed as capital gains and losses as all other investments are taxed. This way, both daily users and investors can obtain the most desirable tax treatment depending on how they use their Bitcoin (Wiseman, Scott A.,2016, p.439).

The NBR press release of March 11, 2015, states that ,the virtual currency is neither a national currency nor a currency, and its acceptance for payment is not legally compulsory. At the same time, the virtual currency does not represent a form of electronic currency, within the meaning of Law no. 127/2011 regarding the activity of issuing electronic money". In the context in which the virtual currencies are not recognized by the Romanian or by the European legislation as currencies, electronic currencies, or real currencies, Bontaș \& Barbu (2019) believe that „the individual acquires a real benefit only when converting these virtual currency units into units of currency, legal currency (e.g. income statement within the bank account) or in goods or services that the individual actually benefits from".

Ionaşcu (2018) believes that "theoretically, the transactions by using Bitcoin or other virtual currencies are anonymous. In fact, this is the main criticism of the cryptocurrencies”. According to Duiu (2020a) ,as long as a person keeps his income from cryptocurrencies in the form of cryptocurrencies, without actually using them, he is not obliged to declare them and pay taxes for them. In other words, the profits obtained from cryptocurrency transactions are not taxed if they do not yet have a purpose in fiat". The income tax does not depend on obtaining income other than from cryptocurrencies, but the Social health insurance contribution does. 
Cernușca, L., Gomoi, B.C., Bilți, R.S., Almași, R.C., (2020)

Study on the taxation of the income obtained from the cryptocurrency transfer

If a person earns money only from cryptocurrencies, then he must pay attention only to the threshold of 600 lei per year and to the one of 12 gross minimum salaries (Boiciuc, 2020).

According to Bakos (2019) "the consideration of the income coming out from the transfer of virtual currency as taxable does not transform such currencies into currencies whose payment acceptance is mandatory". Perhaps there should also be regulations of a constructive nature, not just of a taxable nature (such as the obligation to report profits from virtual currencies in 2019 in order to be declared in 2020).

Duiu (2020b) refers to ,the creation of a legislative framework that would favor the use of blockchain technology in Romania as well. Why wouldn't it be possible? Other countries took this step some time ago, even last year, in September 2019". New Zealand has become the first country that legislated the payment of salaries in cryptocurrencies. Bitcoin, the most popular virtual currency, as well as other digital coins, can serve as a method of paying employees' salaries by the companies. This decision taken by the New Zealand authorities is a first step in introducing Bitcoin (and other digital coins) as a form of payment in everyday situations and highlights the need to regulate them, characterized by decentralization, anonymity, and volatility (Duiu, 2020b). The taxpayer should determine the method of double taxation avoidance convention in the case of the income from abroad and determine the tax credit in Romania.

According to Dumiter \& Jimon (2019, p.15), analyzing the judicial literature we can note that every double taxation avoidance convention is distinctly negotiated. However, lots of double taxation avoidance convention in the world are similar to each other. This fact can be "drawn" to different model conventions made by international organizations. These double taxation avoidance model conventions usually start from bilateral negotiations. The parties involved in negotiations must negotiate only those parts from the Model Convention, which want to deviate".

From the point of view of the expenses, the legislator is not generous in additional regulations, so that in a minimum area of professional reasoning, by expenses related to earning from cryptocurrency we will understand, in the first instance, the expenses with the acquisition of cryptocurrency. Of course, because the taxation has also its charm, it is the obligation of the interested individual to have the supporting documents in order to show the level of expenses related to the gain from cryptocurrency. By default, the lack of supporting documents leads to higher taxation because all the income turns into profit (Zamfir, 2019).

If you receive crypto as a gift, you will not have to recognize any income. Cryptocurrency donations will not trigger a gain or loss (Chandrasekera, 2020). From the point of view of the VAT, we have a decision of the European Court of Justice C 264/2014 David Hedqvist by which the European Court of Justice 
establishes that the exchange of electronic money into a classic currency is not subject to the VAT.

Given that many participants who have invested in cryptocurrencies, at the top of the market they could record losses taking into consideration the recent fluctuations; it should be clarified what happens with these losses from a taxation point of view, says Milcev (2018).

As the enormous potential of this new technology becomes increasingly recognized around the world, the authorities are introducing laws in order to regulate the cryptocurrencies. This is another sign that, in the near future, the cryptocurrencies will lose their volatile, pioneering character and will be brought among the usual financial instruments. And, even as the debate over the cryptocurrencies continues, there is no denying that many people around the world have already felt the benefits of introducing this new technology. For example, those who rely on the amount of money sent by the family members working abroad can use the cryptocurrencies in order to significantly reduce the expenses allocated to the commissions that apply to the transfer of the money from one country to another.

Taking into consideration a not too distant future, it is easy to see how the cryptocurrencies will be able to help those living in regions where it is difficult to access a traditional banking service, thus, giving them the opportunity to participate within the global economy. This could be very applicable for those living in developing countries, says Etoro (2018).

\section{Methodology}

The authors of the article opted for the case study, as a qualitative research method. The approached case studies emphasize descriptive objectives oriented towards understanding the following aspects:

- the method of taxing the gains from the cryptocurrencies;

- the way of reporting the revenues obtained from the cryptocurrencies through the Single Taxation Statement;

- the way of filling the Single Taxation Statement for the taxpayers obtaining earnings from the cryptocurrencies.

\section{Case study and discussion}

\section{Case study no. 1}

An employee from Curtici, Arad County obtained in 2019 revenues from cryptocurrencies in the amount of 10,000 lei (income converted into lei or foreign currency or used to purchase goods or services). The taxpayer submits the single taxation statement on 25 July 2020 via electronic means of remote transmission. 
Cernușca, L., Gomoi, B.C., Bilți, R.S., Almași, R.C., (2020)

Study on the taxation of the income obtained from the cryptocurrency transfer

The taxpayer is not exempt from paying CAS and CASS. We intend to calculate the payment obligations for 2019.

The individual fills in Chapter I of the single taxation statement following the next steps:

CHAPTER I. DATA ON INCOME TAX AND SOCIAL CONTRIBUTIONS DUE FOR 2020

SECTION I.1 Income tax data from Romania

SUBSECTION I.1.1. Data regarding the income tax made in Romania, imposed by the real system / on the basis of flat rates of expenses

\section{I.1.1.A. DATA REGARDING THE ACTIVITY CARRIED OUT}

\subsection{A.1. Income category}

10. Other sources

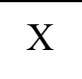

\section{I.1.1.B. DATA REGARDING THE ANNUAL TAX DUE}

\begin{tabular}{|l|l|l|l|}
\hline 1 - Incomes foreseen at & 2 - Income obtained from & 3 - Other incomes than
\end{tabular} art.114 paragraph (2) the transfer of the ones foreseen at art. letter 1 of the Tax Code cryptocurrency foreseen in 114 paragraph (2) letter art. 114 paragraph (2) 1) and $\mathrm{m}$ ) from the Tax letter $\mathrm{m}$ ) of the Tax Code Code

Income.

10.000 lei

Annual tax due/income tax due.

I.5.1. Summary of obligations regarding income tax and social contributions, established by the current statement

1. Income tax......

1.000 lei

1.1. Bonus for full payment until including 30.06 .202 .50 lei

1.2. Bonus for submitting the statement by electronic means .....50 lei

1.3. Payment amount 900 lei

1.4. The taxpayer pays the income tax in the amount of 900 lei on July 30, 2020. 
Cernușca, L., Gomoi, B.C., Bilți, R.S., Almași, R.C., (2020)

Study on the taxation of the income obtained from the cryptocurrency transfer

\section{Case study no. 2}

An individual, member of CECCAR obtains an income from a liberal profession of an accountant. The situation of the estimated net income for the years 2019 and 2020, as well as the one realized for the year 2019, is presented in the table below:

Table 2 Situation of the estimated net income for the years 2019 and 2020, as well as the one realized for the year 2019

\begin{tabular}{|l|l|l|c|c|}
\hline \multirow{2}{*}{} & \multicolumn{2}{|c|}{ Estimated } & \multicolumn{2}{c|}{ Accomplished } \\
\cline { 2 - 5 } & \multicolumn{1}{|c|}{ Gross income } & $\begin{array}{c}\text { Deductible } \\
\text { expenses }\end{array}$ & $\begin{array}{c}\text { Gross } \\
\text { income }\end{array}$ & $\begin{array}{c}\text { Deductible } \\
\text { expenses }\end{array}$ \\
\hline Year 2019 & 10.000 lei & 3.000 lei & 27.500 lei & 4.450 lei \\
\hline Year 2020 & 7.000 lei & 2.000 lei & - & - \\
\hline
\end{tabular}

In 2019, the individual obtained an income consisting of 5,000 lei from cryptocurrencies (income converted into lei or foreign currency or used to purchase goods or services). The taxpayer is not exempted from paying CAS and CASS. We intend to calculate the taxpayer's obligations regarding the income tax and social contributions for 2019 and those estimated for 2020.

- Determination of net income and estimated income tax for 2019.

- The taxpayer electronically submits the single taxation statement via means of remote transmission, respectively through the "Virtual Private Space" (SPV) on July 10, 2019, estimating the gross income and deductible expenses for 2019.

- Estimated net income $2019=10,000$ lei $-3,000$ lei $=7,000$ lei.

- Estimated income tax $2019=7,000$ lei $\times 10 \%=700$ lei.

- Determining the estimated social contributions for 2019.

- As the estimated net income for 2019 does not exceed the limit of 24.960 lei, the taxpayer is not obliged to pay social contributions and he does not decide for their payment either.

- Determination of the net gained income, income tax and social contributions for 2019.

The taxpayer electronically submits the single taxation statement via means of remote transmission, respectively through the "Virtual Private Space" (SPV) on July 25, 2020. In the contents of Chapter I of the single taxation statement, the taxpayer completes his 2019 situation. In this regard the taxpayer fills in the first Chapter of the single taxation statement by following the steps below: 
Cernușca, L., Gomoi, B.C., Bilți, R.S., Almași, R.C., (2020)

Study on the taxation of the income obtained from the cryptocurrency transfer

CHAPTER I. DATA ON THE GAINED INCOME TAX AND SOCIAL CONTRIBUTIONS DUE FOR 2019

SECTION I.1 Income tax data from Romania

SUBSECTION I.1.1 Data on the gained income tax in Romania, imposed in real system / on the basis of flat rates of expenses

\section{$\mathrm{X}$}

\section{I.1.1.A. DATA REGARDING THE ACTIVITY CARRIED OUT}

I.1.1.A.1. Income category

1. Independent activities

I.1.1.A.2. Determination of the net income

1.Real system

$$
\mathrm{X}
$$

I.1.1.A.3. Form of organization

1.Individual

$$
\mathrm{X}
$$

I.1.1.A.4. The main object of activity

CAEN Code Accounting and financial audit activities; tax consultancy

$$
6920
$$

I.1.1.A.5. Headquarters: Arad, no.2a, Coșbuc street I.1.1.A.6. Authorization document

1.Document number: 1

2. Date: 21.12 .2017

I.1.1.A.7. Activity starting date: 01.01 .2018

\section{I.1.1.B. DATA REGARDING THE ANNUAL TAX DUE}

Gross income

Deductible expenses, according to the law

Annual net income (rd.1-rd.2) / Annual net revenue.

Taxable income.

ADD INCOME

\section{I.1.1.A. DATA REGARDED THE ACTIVITY CARRIED OUT \\ I.1.1.A.1. Income category \\ 10.Other sources \\ $\mathrm{X}$}

\section{I.1.1.B. DATA REGARDING THE ANNUAL TAX DUE}


Cernușca, L., Gomoi, B.C., Bilți, R.S., Almași, R.C., (2020)

Study on the taxation of the income obtained from the cryptocurrency transfer

\begin{tabular}{l|l|l|l}
\hline 1 - Income provided at & 2 - Income obtained from & 3 - Other income than
\end{tabular}

art.114 paragraph

(2) cryptocurrency provided in

provided by art. 114

letter 1 of Tax Code art. 114 paragraph. (2)

paragraph. (2) letters 1)

letter $\mathrm{m}$ ) of the Tax Code and $\mathrm{m}$ ) of the Tax Code

Income

5.000 lei

Annual tax due/income tax due

SECTION I.3 Data on social security contributions (CAS) and social health insurance contributions (CASS) due

SUBSECTION I.3.2 Data on the social health insurance contribution due

1. Income obtained for the classification as a CASS payer

Income from self-employment.

23.050 lei

Income from other sources

TOTAL

28.050 lei

2. The annual calculation base of CASS (Number of months $x$ Minimum salary)

24.960 lei

3.CASS due (row.2 x 10\%)

SECTION I.4 Determination of the annual tax due on net annual taxable income obtained from self-employed activities and intellectual property rights, imposed in the real system

$$
\mathrm{X}
$$

1.The amount of net income from self-employment and rights of

intellectual property, imposed in real system

23.050 lei

2.CAS

0 lei

3. Annual tax income (row.1-row.2)

23.050 lei

4. Reduced annual net taxable income 0 lei

5. Total annual tax due (row. $3 \times 10 \%$ or row. $4 \times 10 \%$ )

2.305 lei

I.5.1. Summary of the obligations regarding the income tax and social contributions, established by the current statement.

1. Income tax 
1.1. Bonus for full payment until 30.06.2020 inclusive

1.2. Bonus for submitting the single taxation statement via electronic means 140 lei

1.3. Payment amount 2.525 lei

2. Social insurance contribution ..... 0 lei

3. Social health insurance contribution 2.496 lei

3.1. Bonus for full payment until 30.06.2020 inclusive 125lei

3.2. Bonus for submitting the single taxation statement via electronic means 125 lei 3.3. Payment amount 2.2461ei In Chapter II of the single taxation statement filed on July 25, 2020, the taxpayer estimates his gross income and deductible expenses for 2020. To this end, the taxpayer completes Chapter II single taxation statement by following these steps:

CHAPTER II. ESTIMATED INCOME TAX DATA / INCOME RULE TO BE MADE IN ROMANIA AND SOCIAL CONTRIBUTIONS DUE FOR 2020 SECTION II.1. Data on the estimated income tax in Romania SUBSECTION II.1.1 Data on the estimated income tax in Romania, imposed in the real system / on the basis of flat rates of expenditur

\section{$\mathrm{X}$}

\section{II.1.1.A.DATA REGARDING THE ACTIVITY CARRIED OUT \\ II.1.1.A.1. Income category \\ 1. Independent activities \\ $\mathrm{X}$}

II.1.1.A.2. Determining the net income

1.Real system

$$
\mathrm{X}
$$

\section{II.1.1.A.3. Organization form}

1.Individual

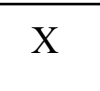

II.1.1.A.4. The main activity object

CANE Code Accounting and financial audit activities; tax consultancy

$$
6920
$$

II.1.1.A.5. Headquarters: Arad, no.2a, Coșbuc street

II.1.1.A.6. Authorization document

1. Document number: 1

2.Date: 21.12 .2017

II.1.1.A.7. Activity starting date: 01.01 .2018 


\section{II.1.1.B. DATA REGARDING THE ANNUAL TAX DUE}

1. Gross income 7.000 lei

2. Deductible expenses 2.000 lei

3. Estimated annual net income (rd.1-rd.2) out of which 5.000 lei 3.1. Taxable income 5.000 lei

4. Estimated annual tax (rd.3.1x 10\%) .500 lei

In 2020, as the estimated net income does not exceed the legal limit of 26,760 lei (2,230 lei/month x 12 months), the taxpayer does not owe social contributions estimated for 2020 and does not choose to pay them either.

\section{II.3. Summary of estimated income tax obligations and estimated social} contributions due set out through the current statement

II.3.1. Estimated income tax obligations

1. The amount determined by the current statement. 500 lei

2. The bonus for the full tax payment, according to the law 0 lei

\section{Conclusions}

By the Law no. 30/2019 for the approval of the GEO no. 25/2018, the Romanian legislators regulated the tax regime applicable to the incomes from the virtual currency transfer, thus eliminating the uncertainties that hovered over the taxation regime of these incomes. Thereby, we are witnessing a necessary adaptation of the Romanian legal and tax context to the entry of the cryptocurrencies in the circuit of the financial operations. The cryptocurrencies have emerged in the mainstream of the financial operations out of the need to use an alternative currency, which is easy to transfer and which does not require the presence of a managing authority. They serve as a purely digital, cashless exchange medium. The individuals who earn constant money from cryptocurrencies (over 600 lei per year) have the obligation to report yearly, through the Single Taxation Statement, their income, income tax, and health contribution in certain situations. Specifically, the earnings from cryptocurrencies from 2019 are declared, through the Single Taxation Statement, in 2020. Thus, it reports the gains they had in 2019, i.e. the difference between the sale price and the purchase price, including the direct costs related to the transactions with cryptocurrencies. The taxation of cryptocurrency earnings should be detailed through the rules of the application of the Tax Code in order to remove any problems related to the time of determination of the gain, the direct costs of transactions that can be deducted from the tax base or the necessary supporting documents. The price of the cryptocurrencies can fluctuate significantly and, thus, should be clarified what happens in the situation where there have been 
Cernușca, L., Gomoi, B.C., Bilți, R.S., Almași, R.C., (2020)

Study on the taxation of the income obtained from the cryptocurrency transfer

losses from a tax point of view, taking into consideration the recent fluctuations for those who have invested in cryptocurrencies at the top of the market. In the years to come, cryptocurrencies will lose their pioneering character and they will be surely found among the usual financial instruments.

\section{Acknowledgments}

The authors thank the anonymous reviewers and editor for their valuable contribution.

\section{Funding}

This research received no specific grant from any funding agency in the public, commercial, or not-for-profit sectors.

\section{Author Contributions}

Lucian Cernuşca conceived and organized the practical part and the case studies of the paper. Bogdan Cosmin Gomoi elaborated on the literature review and emphasized the research methodology. Raluca Simina Bilți was responsible for the conceptual framework, namely the introduction of the paper and its design. Robert Cristian Almasi built up the conclusions and elaborated on the list of the references.

\section{Disclosure Statement}

The authors have not any competing financial, professional, or personal interests from other parties.

\section{References}

1. Ankier, A., (2020). Debugging IRS Notice 2014-21: Creating a Viable Cryptocurrency Taxation Plan. Brooklyn Law Review. Volume 85, Issue 3. Available at: https://brooklynworks.brooklaw.edu/blr/vol85/iss3/7.

2. Bakos, A., (2019). Câștigi bani din criptomonede? Dacă treci de o anumită limită, din 2019 datorezi impozit, Retrieved https://www.avocatnet.ro/articol 50026/Ca\%C $8 \% 99$ tigi-bani-din-criptomonedeDac\%C4\%83-treci-de-o-anumit\%C4\%83-limit\%C4\%83-din-2019-datorezi-impozit.html ， Accessed August, $8^{\text {th }}, 2020$.

3. Banu, C.M., Clam, F., (2019). Aspecte de actualitate privind reglementarea tehnologiei registrelor distribuite și a monedelor virtuale în legislația statelor membre ale Uniunii europene, Retrieved from: http://www.cdep.ro/afaceri europene/afeur/2019/st 2643.pdf , Accessed August, $12^{\text {th }}, 2020$.

4. Boiciuc, A., (2020). 2020 e primul an în care se declară la Fisc câștigurile din criptomonede. Declarația unică, modificată deja pentru asta, Retrieved from: https://www.avocatnet.ro/articol 52220/2020-e-primul-an-in-care-se-declar\%C4\%83-laFisc-ca\%C $8 \% 99$ tigurile-din-criptomonede-Declara\%C $8 \% 9$ Bia-unic\%C $4 \% 83$ modificat\%C4\%83-deja-pentru-asta.html, Accessed September, $20^{\text {th }}, 2020$. 
Cernușca, L., Gomoi, B.C., Bilți, R.S., Almași, R.C., (2020)

Study on the taxation of the income obtained from the cryptocurrency transfer

5.Bontaș, R. \& Barbu, C., (2019), Criptomonedele și prima reglementare specifică din legislația națională prin Codul fiscal, Retrieved from: https://www2.deloitte.com/ro/ro/pages/tax/articles/criptomonedele-si-prima-reglementarespecifica-din-legislatia-nationala-prin-codul-fiscal.html , Accessed September $5^{\text {th }}, 2020$

6. Chandrasekera, S., (2020). New IRS Cryptocurrency Tax Guidance And Key Highlights. Today's CPA January/February, pp. 7-8.

7.Ciutacu, A., (2019). Este oficial: Începând de acum câştigurile din bitcoin se declară şi se impozitează prin Declaraţia Unică. Tot ce trebuie să ştii, Retrieved from: https://www.zf.ro/burse-fonduri-mutuale/este-oficial-incepand-de-acum-castigurile-din-

bitcoin-se-declara-si-se-impoziteaza-prin-declaratia-unica-tot-ce-trebuie-sa-stii-17846025, Accessed September $12^{\text {th }}, 2020$

8. Duiu, C., (2020 a). Câștigurile din criptomonede se declară la ANAF în 2020, Retrieved from: https://ldvbank.com/ro/blog/castigurile-din-criptomonede-se-declara-la-anaf-in-202079/, Accessed August 20 $0^{\text {th }}, 2020$.

9. Duiu, C., (2020 b). Implementarea blockchain, Noua Zeelandă şi plata salariilor în Bitcoin, Retrieved from https://ldvbank.com/ro/blog/implementarea-blochchain-nouazeelanda-si-plata-salariilor-in-bitcoin-78/, Accessed July, $25^{\text {th }}, 2020$.

10. Dumiter, F., \& Jimon, Ș. (2019). Avoiding Double Taxation Through the Assessment of International Tax Treaties. Case: ESP's versus Anaf BRAȘOV Journal of Legal Studies, 23(37):1-15 DOI: 10.2478/jles-2019-0001.

11. Etoro, (2018). Tehnologia care mișcă lumea criptomonedelor, Retrieved from: https://www.etoro.com/ro/news-and-analysis/market-insights/cryptotechnology/?gclid=CjwKCAjwn9v7BRBqEiwAbq1Ey1QNNL8nI3rhkpJvw_XUCvsfGj5k ZWGUWEk6sVpS64IFx7-TyyyhsBoCx5kQAvD_BwE, Accessed September, $2^{\text {nd }}, 2020$

12. Houben, R., Snyers, A., (2018). Cryptocurrencies and blockchain - Legal context and implications for financial crime, money laundering, and tax evasion. Retrieved from: https://www.europarl.europa.eu/cmsdata/150761/TAX3\%20Study\%20on\%20cryptocurrenc ies\%20and\%20blockchain.pdf, Accessed September, 5 ${ }^{\text {th }}, 2020$.

13. Ionașcu, D., (2018). Românii cu Bitcoin, datori la Fisc. Trebuie plătit impozit pe venit și contribuții sociale, deși monedele virtuale nu sunt reglementate în România, Retrieved from: https://www.libertatea.ro/stiri/exclusiv-romanii-cu-bitcoin-datori-la-fisc-trebuie-platitimpozit-pe-venit-si-contributii-sociale-desi-monedele-virtuale-nu-sunt-reglementate-inromania-2163395, Accessed August $12^{\text {th }}, 2020$.

14.Lerer, M., (2020). The Taxation of Cryptocurrency. Virtual Transactions Bring Real-Life Tax Implications, CPA Journal, February Issue 2020.

15.Mantu, I. M., (2019), Criptomonedele - Impozitarea veniturilor din criptomonede, Retrieved from: https://www.legistm.ro/blog/impozitarea-veniturilor-din-criptomonede, Accessed August 12 $2^{\text {th }}, 2020$.

16.Milcev, A., (2018), Tranzacţionarea cripto-monedelor - o piaţă mult prea mare pentru a rămâne în afara legislaţiei fiscale, Retrieved from:

https:/www.zf.ro/opinii/opinie-alex-milcev-ey-tranzactionarea-cripto-monedelor-o-piatamult-prea-mare-pentru-a-ramane-in-afara-legislatiei-fiscale-17023753, Accessed August $18^{\text {th }}, 2020$. 
Cernușca, L., Gomoi, B.C., Bilți, R.S., Almași, R.C., (2020)

Study on the taxation of the income obtained from the cryptocurrency transfer

17.Semanski, K.R., (2018). Income, from Whatever Exchange, Mine, or Fork Derived: The Basics of U.S. Cryptocurrency Taxation. Banking \& Financial Services Policy Report, Volume 37, Number 6, June 2018, pp. 8-18.

18. Tradesilvania, (2020), În 2020, românii care au avut venituri din tranzacțiile crypto, vor plăti impozit și chiar CASS ,Retrieved from: https://tradesilvania.com/blog/in-2020romanii-care-au-avut-venituri-din-tranzactiile-crypto-vor-plati-impozit-si-chiar-cass/ , Accessed September $15^{\text {th }}, 2020$.

19. Wiseman, Scott A., (2016). „Property or Currency? The Tax Dilemma Behind Bitcoin” Utah Law Review: Vol. 2016: No. 2, Article 5. Available at: http://dc.law.utah.edu/ulr/vol2016/iss2/5.

20. Zamfir, C., (2019), Consultantul fiscal Adrian Bența: Declarația unică şi impozitarea veniturilor din Bitcoin și alte criptomonede, Retrieved from: https://www.startupcafe.ro/taxe/impozit-bitcoin-criptomonede-declaratia-unica-2019.htm, Accessed July $30^{\text {th }}, 2020$.

21. Decizia Curții Europene de Justiție C 264/2014 David Hedqvist http://curia.europa.eu/juris/document/document.jsf?docid=170305\&doclang=RO.

22. *** Law no. $227 / 2015$ on the Tax Code, published in the Official Gazette no. 688 / 10.09.2015, with subsequent amendments and completions.

23. *** Government Decision 1/2016 for the approval of the Methodological Norms for the application of Law no. 227/2015 on the Tax Code, published in the Official Gazette no. 22 / 13.01.2016 with subsequent amendments and completions.

24. *** Order of the President of ANAF no. 49 of January 11, 2019, for the approval of the model, content, method of submission, and management of the form "Single taxation statement of income tax and social contributions due by individuals" published in the Official Gazette no. 43 of January 16, 2019.

25. *** Order no. 1886/2019 on amending and supplementing the Order of the President of the National Agency for Fiscal Administration no. 49/2019 for the approval of the model, content, method of submission, and management of the form "Single taxation statement of income tax and social contributions due by individuals" published in the Official Gazette no. 561 of July 9, 2019. 